\title{
Weryfikacja wybranych zastosowań hipotezy rynku adaptacyjnego na rynkach finansowych
}

\section{Streszczenie}

Hipoteza rynku adaptacyjnego (adaptive market hypothesis - AMH), której autorem jest A. Lo, to jeden z najnowszych modeli opisujących działanie rynków finansowych. AMH stanowi rozwinięcie hipotezy rynku efektywnego (efficient market hypothesis EMH), która pozwala na połączenie EMH z wnioskami wynikającymi z finansów behawioralnych. W artykule przedstawione zostały główne założenia, wnioski oraz badania empiryczne dotyczące AMH. Celem artykułu jest empiryczna weryfikacja wybranych wniosków wynikających z hipotezy rynku adaptacyjnego w warunkach polskiego rynku. Analizie poddano wnioski dotyczące istnienia relacji pomiędzy zyskiem a ryzykiem oraz skuteczności strategii inwestycyjnych. Zgodnie z AMH inwestorzy oczekują wyższych stóp zwrotu, gdy podejmują większe ryzyko, wymagana premia za ryzyko nie jest jednak stała w czasie. Drugi wniosek dotyczy tego, że skuteczność strategii inwestycyjnych zależna jest od miejsca i czasu ich zastosowania. Badania zostały przeprowadzone na przykładzie spółki KGHM Polska Miedź SA, indeksu WIG oraz DAX. Wniosek pierwszy został sprawdzony za pomocą modelu wyceny aktywów kapitałowych, natomiast wniosek drugi z wykorzystaniem strategii inwestycyjnej opartej na tzw. efekcie stycznia. Oba wnioski okazały się poprawne.

Słowa kluczowe: hipoteza rynku adaptacyjnego, CAPM, finanse behawioralne, hipoteza rynku efektywnego.

Klasyfikacja JEL: G11, G12, G14.

Michał Kasolik, Uniwersytet Ekonomiczny w Krakowie, Studia Doktoranckie Wydziału Zarządzania, 31-510 Kraków, ul. Rakowicka 27, e-mail: michalkasolik@wp.pl 


\section{Wprowadzenie}

Istnieje spora grupa teorii inwestycyjnych opartych na założeniach hipotezy rynku efektywnego (efficient market hypothesis - EMH), zgodnie z którymi uczestnicy rynku uważani są za jednostki racjonalne, działające zawsze we własnym interesie i podejmujące optymalne decyzje w zależności od występującego prawdopodobieństwa i funkcji użyteczności [Reilly i Brown 2001]. Założenia te stały się przedmiotem krytyki ze strony ekonomistów reprezentujących nurt tzw. finansów behawioralnych. Udokumentowali oni liczne odstępstwa od zasad występujących w hipotezie rynku efektywnego w postaci specyficznych behawioralnych zachowań, które towarzyszą decyzjom podejmowanym w warunkach niepewności i prowadzą do niepożądanych rezultatów dla dobrobytu jednostek [Lo 1997]. Przykłady takich zachowań zostały najszerzej opisane w badaniach D. Kahnemana i A. Tversky'ego [1979 i 1982]. Rezultaty ich badań wskazywały m.in. na to, że większość jednostek jest znacząco bardziej pewna wiedzy, niż wskazuje na to stan faktyczny, więc jest zbyt pewna siebie, ponadto jednostki ustalają prawdopodobieństwo zdarzeń nie na podstawie aksjomatów teorii prawdopodobieństwa, lecz tego, jak reprezentatywne są zdarzenia w ogólnej klasie zjawisk branych pod uwagę. Dodatkowo większość badanych miała tendencję do odczuwania awersji do ryzyka w odniesieniu do wzrostów, natomiast w odniesieniu do spadków charakteryzowała się wysoką tolerancją na ryzyko. Głównym problemem finansów behawioralnych jest niedostatek fundamentalnych aksjomatów. Zwolennicy EMH często krytykują finanse behawioralne, stwierdzając, że behawioralne tendencje i nieefektywność pojawiają się od czasu do czasu, ale są krótkotrwałe, ponieważ działający na rynkach arbitrażyści, wykorzystując nieefektywność rynków, powodują jednocześnie ich zanikanie [Shiller 2003]. Ponadto zwolennicy EMH twierdzą, że finanse behawioralne stanowią teorię za mocno opierającą się na spostrzeżeniach i że jest ona zbiorem obserwacji bez żadnych jednolitych reguł wyjaśniających ich pochodzenie [Malkiel 2014]. Pomimo krytycznych uwag, żadna teoria nie zdołała wyprzeć EMH. Jest to prawdopodobnie spowodowane ogromnym wkładem EMH w rozwój teorii i praktyki nowoczesnych finansów.

$\mathrm{Z}$ połączenia hipotezy rynku efektywnego $\mathrm{z}$ wnioskami wynikającymi $\mathrm{z}$ finansów behawioralnych powstała hipoteza rynku adaptacyjnego (adaptive market hypothesis - AMH), której autorem jest A. Lo [2004]. Jest ona jednym z najnowszych modeli opisujących działanie rynków finansowych.

Celem artykułu jest przeprowadzenie w warunkach polskiego rynku empirycznej weryfikacji dwóch wniosków wynikających z hipotezy rynku adaptacyjnego. Analizie poddano wnioski AMH dotyczące istnienia relacji pomiędzy zyskiem a ryzykiem oraz skuteczności strategii inwestycyjnych. Badania przeprowadzono na przykładzie spółki KGHM Polska Miedź SA, indeksu WIG 
oraz DAX. Jeśli założymy, że model ten jest poprawny, powinna istnieć relacja pomiędzy zyskiem a ryzykiem, a skuteczność strategii inwestycyjnych powinna być zmienna w czasie.

\section{Podstawy teoretyczne hipotezy rynku adaptacyjnego}

Hipoteza rynku adaptacyjnego [Lo 2004] opiera się na zasadach ewolucji: konkurowaniu, reprodukcji i naturalnej selekcji. Zdaniem zwolenników modelu siły te determinują efektywność rynków oraz wzrost lub spadek rentowności instrumentów finansowych, biznesu, przemysłu, a także inwestycji indywidualnych.

Zastosowanie idei procesów ewolucyjnych w teorii ekonomii ma długą historię. Powszechnie znane są poglądy T. Malthusa, który twierdził, że populacja rośnie $\mathrm{w}$ tempie wykładniczym, a zasoby naturalne w tempie arytmetycznym. Inni znani naukowcy, którzy wykorzystywali procesy ewolucyjne w swoich teoriach, to m.in.:

- J. Schumpeter [1939] - autor teorii wzrostu gospodarczego i cyklów koniunkturalnych indukowanych przez przełomowe innowacje, teorii postępującej transformacji kapitalizmu w socjalizm, historyk myśli ekonomicznej. Był zwolennikiem tezy o dominującej roli elit i wybitnych jednostek w rozwoju społeczno-gospodarczym;

- E.O. Wilson [1975] - był jednym z pierwszych, który zastosował zasady konkurencji i doboru naturalnego ${ }^{1}$ do wyjaśnienia interakcji społecznych, otrzymując przekonujące wyjaśnienia pewnych ludzkich zachowań, takich jak: altruizm, uczciwość, moralność, sposób wybierania partnerów;

- P. Bernstein - twierdził, że równowaga zakładana w EHM jest rzadka ze względu na dynamiczny rozwój rynków.

Istotne znaczenie dla rozwoju hipotezy rynku adaptacyjnego miały prace noblisty H. Simona [1955]. Jego zainteresowania skupiały się na tym, w jaki sposób realni ludzie - nie nieskończenie mądrzy, racjonalni i inteligentni podejmują decyzje. Stwierdził m.in., że ludzie nie dążą do optymalizacji swoich decyzji, ponieważ wymaga ona dużo wysiłku i jest kosztowna, lecz dokonują raczej wyboru, który można uznać jako satysfakcjonujący (spełniający minimalne wymagania).

Pojawia się pytanie, kiedy ludzie przestają optymalizować i wybierają satysfakcjonujący rezultat. A. Lo [2005] proponuje rozwiązanie tego problemu w następujący sposób: punkt satysfakcji nie jest określany analitycznie, a na podstawie prób i błędów oraz oczywiście doboru naturalnego, którego miarą jest dostosowywanie

${ }^{1}$ Dobór naturalny (selekcja naturalna) - jeden z mechanizmów ewolucji biologicznej, prowadzący do ukierunkowanych zmian w populacji zwiększających ich przeciętne przystosowanie, czyli adaptację do warunków środowiskowych, poza okresem wymierania. 
się do nowych warunków. Pojedyncze osoby podejmują działania na podstawie swoich doświadczeń i swoich wyobrażeń dotyczących tego, co może być najlepsze, a następnie na podstawie rezultatów uczą się, czy podjęły dobrą decyzję. Jeżeli dany problem pozostaje nierozwiązany (stan świata się nie zmienia), dochodzi po pewnym czasie do wyboru optymalnych rozwiązań, rozwinięcia skrótów myślowych (heurystyki) i powstania równowagi. Jakakolwiek zmiana warunków środowiska powoduje, że dane rozwiązanie nie jest już poprawne. Dochodzi do anomalii opisywanych przez finanse behawioralne, ale złe rezultaty zmuszają jednostki do ponownego poszukiwania najlepszego rozwiązania, co prowadzi do kolejnej adaptacji i optymalizacji działań.

A. Lo na podstawie powyższych argumentów oraz dokonań teorii ewolucyjnych i socjobiologicznych ostatnich 20 lat stworzył model hipotezy rynku adaptacyjnego. Nie jest on według autora zaprzeczeniem hipotezy rynku efektywnego, a wyłącznie jej rozszerzeniem. Podstawowe założenia AMH są następujące [Lo 2005]:

1) jednostki działają egoistycznie (dążą do osiągania zysków),

2) jednostki popełniają błędy,

3) jednostki uczą się i adaptują,

4) rywalizacja napędza procesy adaptacyjne i innowacyjne,

5) dobór naturalny kształtuje środowisko rynków,

6) ewolucja determinuje rozwój rynków.

AMH i EMH mają wspólny pierwszy punkt, różnice pojawiają się natomiast w punktach drugim i trzecim. Według klasycznej teorii na rynkach efektywnych inwestorzy nie popełniają błędów. Nie zachodzi proces uczenia się i adaptacji, ponieważ rynek jest zawsze w stanie równowagi i nie zmienia się. AMH zakłada natomiast, że błędy zdarzają się często, ale jednostki są zdolne do wyciągania z nich wniosków i do adaptacji. Jak wskazuje punkt czwarty, adaptacja ta nie zachodzi jednak niezależnie od warunków panujących w środowisku rynkowym, ale napędzana jest rywalizacją, tj. dążeniem do przetrwania. Punkt piąty oznacza, że przetrwają najsilniejsi, czyli że obecny stan rynków jest wynikiem doboru naturalnego. Punkt szósty można uznać za wynikający z poprzednich założeń - samolubne jednostki, rywalizacja, adaptacja, dobór naturalny i warunki środowiska rynkowego powodują rozwój rynków. Główne zależności wynikające z hipotezy rynku adaptacyjnego to [Lo 2005]:

1) efektywność rynków zależy od kombinacji warunków środowiska oraz liczby tzw. gatunków (każda grupa uczestników to jeden gatunek; jednym z gatunków mogą być fundusze inwestycyjne, kolejną inwestorzy indywidualni itd.). Jeśli wiele gatunków rywalizuje o małe zasoby na danym rynku, rynek ten będzie bardziej efektywny. Przykładowo rynek obligacji amerykańskich, który ma wielu uczestników, reaguje bardzo szybko na nowe informacje. Z drugiej strony mała liczba 
uczestników rywalizująca o duże zasoby na danym rynku powoduje, że rynek ten będzie mało efektywny. Oznacza to, że efektywność rynków musi być rozpatrywana w kontekście zmieniających się warunków, takich jak np. zmienna liczba gatunków;

2) zmienność preferencji. Preferencje danego inwestora będą się zmieniać w zależności od sytuacji, w jakiej się on znajduje. Przykładowo częstym sposobem określania czyichś preferencji stosowanym przez doradców finansowych jest przeprowadzanie ankiet. Załóżmy, że osoba 35-letnia wypełnia ankietę przed stratą współmałżonka i po jego stracie. Wydaje się rzeczą oczywistą, że odpowiedzi przed tym tragicznym momentem i po nim będą różne;

3) istnieje zależność między ryzykiem a zyskiem, nie jest ona jednak stabilna. Relacja pomiędzy zyskiem a ryzykiem zależy od preferencji wielu gatunków, a także środowiska, w którym działają - środowiska prawnego, regulacji, podatkowego. Ponieważ są to czynniki zmienne, zmienia się też opisywana relacja. Przykładowo przez dłuższy czas hossy inwestorzy wyrobią sobie nawyki, które są potem nieprzydatne w czasie bessy. Ci, którzy przeżyli już kiedyś wcześniej bessę, mają szansę przetrwać, natomiast duża liczba inwestorów opuści rynek, co będzie miało wpływ na postrzeganie ryzyka czy zysku;

4) okazje do arbitrażu istnieją, ale ich pojawianie się i znikanie jest cykliczne. Jak zaobserwowali S. Grossman i J. Stliglitz [1980], gdyby nie było możliwości arbitrażu, nie byłoby sensu gromadzić i analizować danych. Zgodnie z AMH wraz ze zmianą warunków (np. nowe gatunki) pojawiają się takie okazje, ale po pewnym czasie znikają. Nie oznacza to, że już się później nie pojawią. Gdy warunki temu sprzyjają, dana strategia arbitrażowa może znów zadziałać (np. rynek fuzji czy korelacje). Liczne przykłady występowania możliwości arbitrażu na rynkach finansowych przedstawili m.in. A. Schleifer i R. Vishny [1997] oraz F. Akram, D. Rime i L. Sarno [2007];

5) strategie inwestycyjne są skuteczne lub nieskuteczne w zależności od sytuacji rynkowej (sytuacja podobna do opisanej w pkt 4). Jedne strategie mogą działać dobrze w danym środowisku (na danym rynku), a w innym już nie. Przykładem jest inwestowanie w wartość lub we wzrost. Zastosowanie danego typu strategii w zależności od czasu lub miejsca może mieć różne rezultaty;

6) kluczem do przeżycia jest innowacja. O ile EMH sugeruje, że aby osiągnąć wyższe zyski, trzeba jedynie zaakceptować wyższe ryzyko, o tyle hipoteza rynku adaptacyjnego wskazuje raczej na przystosowanie się do zmieniającego się otoczenia (nie sposób działać identycznie w każdych warunkach). 


\section{Empiryczna weryfikacja hipotezy rynku adaptacyjnego}

Badania nad AMH na zagranicznych rynkach potwierdzą wnioski wynikające z tego modelu. W swojej pracy A. Todea, M. Ulici i S. Silaghi [2009] wykazali, że opłacalność strategii inwestycyjnej na rynkach azjatyckich oparta na średniej ruchomej nie jest stała w czasie. J.H. Kim, H. Shamsuddin i L. Kian-Ping [2011] udowodnili, że wpływ zmienności warunków rynkowych na zyskowność inwestowania na rynku amerykańskim jest zgodny z modelem hipotezy rynku adaptacyjnego. S. Popović, A. Mugoša i A. Durović [2013], analizując rynek akcji w Czarnogórze, doszli do wniosku, że rynek ten charakteryzuje się zmienną efektywnością. L. Kian-Ping [2007] w swoich badaniach również dowodził różnorodnej efektywności rynków.

W niniejszym artykule weryfikacji zostaną poddane wnioski o zależności pomiędzy ryzykiem a zyskiem oraz o skuteczności strategii inwestycyjnych. Pierwszy z nich zostanie sprawdzony za pomocą modelu wyceny aktywów kapitałowych (capital assets pricing model - CAPM), natomiast drugi za pomoca strategii inwestycyjnej opartej na tzw. efekcie stycznia.

Zgodnie z AHM istnieje zależność między ryzykiem a zyskiem, nie jest ona jednak stabilna. Jako miarę ryzyka przyjęto współczynnik $\beta$, wynikający z modelu CAPM. Zgodnie z tym modelem istnieje liniowa zależność pomiędzy zyskiem a ryzykiem, a premia za ryzyko jest determinowana przez dodatni współczynnik $\beta$ określany wzorem [Elton i Gruber 1998]:

$$
\beta_{i}=\frac{\operatorname{cov}\left(r_{i}, r_{m}\right)}{\sigma_{m}^{2}},
$$

gdzie:

$\beta_{i}$ - współczynnik $\beta i$-tego instrumentu finansowego,

$r_{i}$ - stopa zwrotu $\mathrm{z} i$-tego instrumentu finansowego,

$r_{m}$ - stopa zwrotu z portfela.

Zgodnie z teorią spółki o wysokich współczynnikach $\beta$ powinny charakteryzować się wyższymi stopami zwrotu niż spółki charakteryzujące się niższymi współczynnikami $\beta$. Model CAPM implikuje, że stopa zwrotu z ryzykownych inwestycji może być określona przez równanie linii rynków papierów wartościowych (SML) [Elton i Gruber 1998]:

$$
E\left(r_{i}\right)=r_{f}+\beta_{i}\left[E\left(r_{m}\right)-r_{f}\right],
$$

gdzie:

$E\left(r_{i}\right)$ - oczekiwana stopa zwrotu z portfela $i$,

$r_{f}$ - stopa zwrotu z instrumentu wolnego od ryzyka,

$\beta_{i}-$ współczynnik $\beta i$-tego portfela,

$E\left(r_{m}\right)$ - oczekiwana stopa zwrotu z portfela rynkowego. 


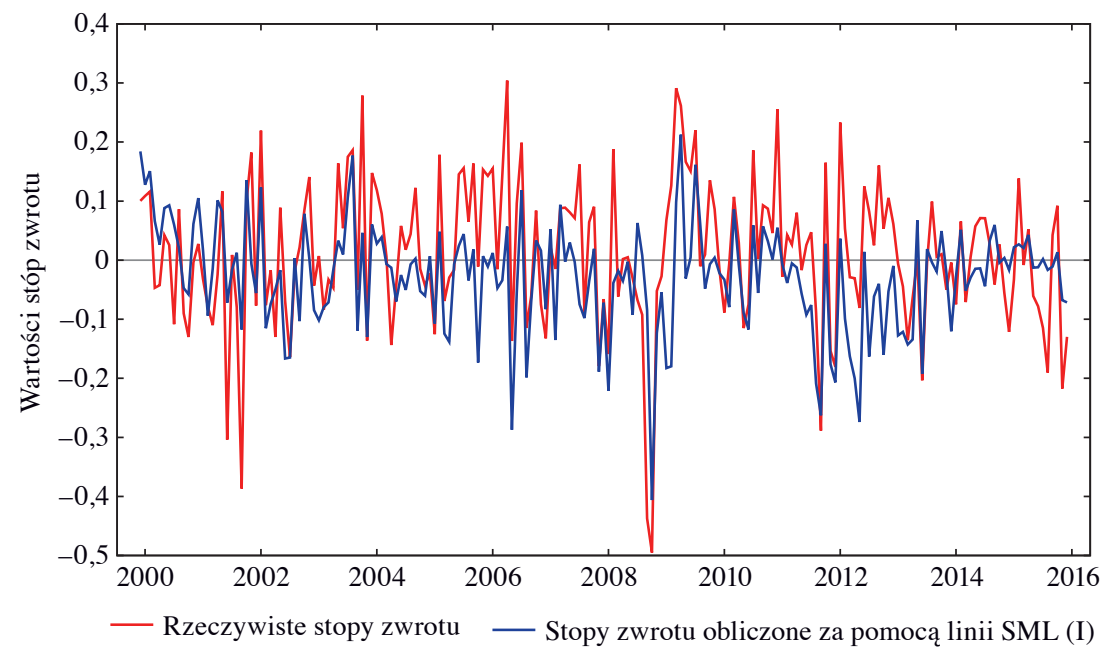

Rys. 1. Wartości stóp zwrotu rzeczywistych i obliczonych za pomocą linii SML ( $\beta$ obliczana metodą I)

Źródło: opracowanie własne.

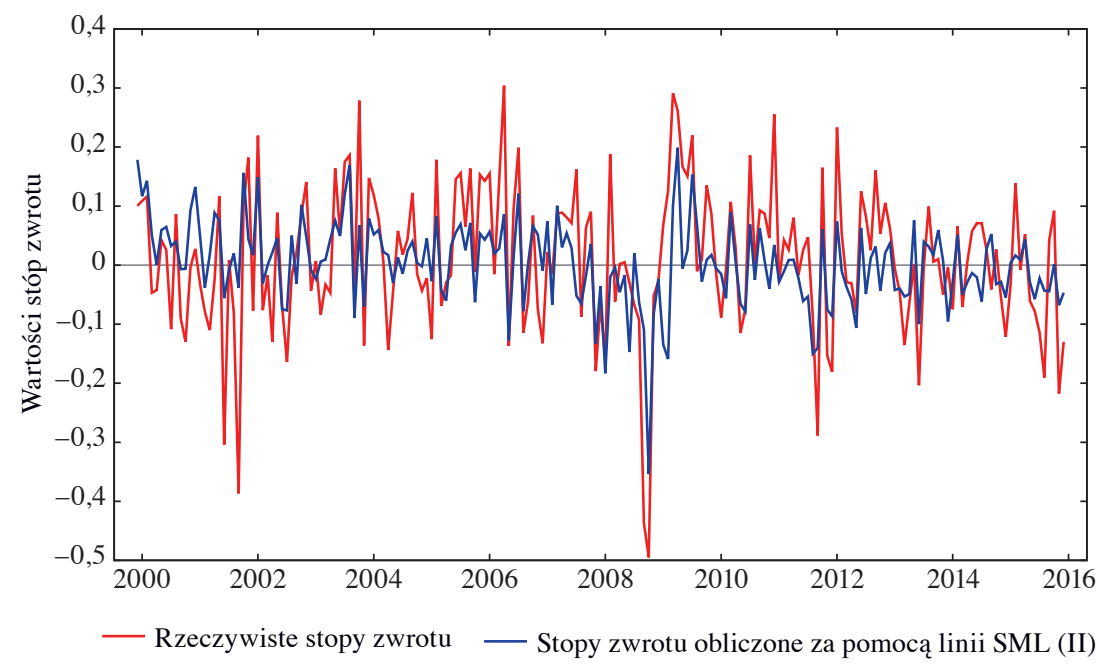

Rys. 2. Wartości stóp zwrotu rzeczywistych i obliczonych za pomocą linii SML ( $\beta$ obliczana metodą II)

Źródło: opracowanie własne. 
Jeśli wniosek o zależności pomiędzy ryzykiem a zyskiem AMH jest poprawny, to współczynnik $\beta$ nie powinien być stały w czasie oraz powinna istnieć statystycznie istotna zależność pomiędzy rzeczywistą stopą zwrotu a tą wynikającą z modelu CAPM.

Problemem Giełdy Papierów Wartościowych w Warszawie jest niska płynność, która może powodować zakłócenia w procesie wyceny aktywów. Z tego powodu do badania wybrano spółkę KGHM Polska Miedź SA, której akcje charakteryzują się wysoką płynnością [Olbrys 2014]. Za portfel rynkowy przyjęto indeks WIG. Jest to indeks giełdowy, który obejmuje największą liczbę polskich spółek, dlatego można uznać go za najlepszy odpowiednik portfela rynkowego w Polsce. Do wyliczeń posłużyły dane miesięczne z lat 1997-2015. Stopa wolna od ryzyka została ustalona na poziomie oprocentowania lokat międzybankowych. Pierwszego zakupu portfela dokonano w styczniu 2000 r. Badania przeprowadzono, wykorzystując dwa sposoby obliczeń. Według pierwszego współczynnik $\beta$ był uaktualniany co miesiąc, tak aby zawierał wszystkie dostępne dane. Drugi sposób opierał się na założeniu, że współczynnik $\beta$ obliczany jest na podstawie ostatnich 24 miesięcy notowań. W pracy przyjęto poziom istotności na poziomie $\alpha=0,05$.

Pierwszy etap analizy opierał się na wyliczeniu stóp zwrotu według modelu CAPM i oszacowaniu funkcji liniowej, gdzie zmienną objaśnianą jest stacjonarny proces stóp zwrotu spółki KGHM (rozszerzony test Dickeya-Fullera wykazał $p$-value na poziomie $2,544 \mathrm{e}-012$ ), a zmienną objaśniającą stopy zwrotu według linii SML (rys. 1 i 2). Jeśli relacja opisywana przez linię SML jest prawdziwa, powinna ona tłumaczyć kształtowanie się rzeczywistych stóp zwrotów.

Rezultaty estymacji wskazują, że relacja wynikająca z równania linii SML jest statystycznie istotna w obu przypadkach (tabela 1). W przypadku metody I wyjaśnia ona ok. 36\% zmienności poziomu stóp procentowych, natomiast w przypadku metody II - w przybliżeniu 43\%. Ponadto w obu przypadkach statystyka DW jest większa od $R^{2}$, co wskazuje na to, że związek pomiędzy rzeczywistą stopą zwrotu a tą wynikającą z modelu CAPM nie powinien być pozorny.

Tabela 1. Estymacja KMNK dla procesu $\beta$

\begin{tabular}{|l|c|c|}
\hline \multicolumn{1}{|c|}{ Wyszczególnienie } & Metoda I & Metoda II \\
\hline $\begin{array}{l}\text { Test istotności dla współczynnika } \\
\text { zmiennej objaśniającej }(p \text {-value) }\end{array}$ & 0,0000 & 0,0000 \\
\hline Skorygowany $R^{2}$ & 0,36 & 0,43 \\
\hline Statystyka Durbina-Watsona & 1,26 & 1,46 \\
\hline
\end{tabular}

Źródło: opracowanie własne. 


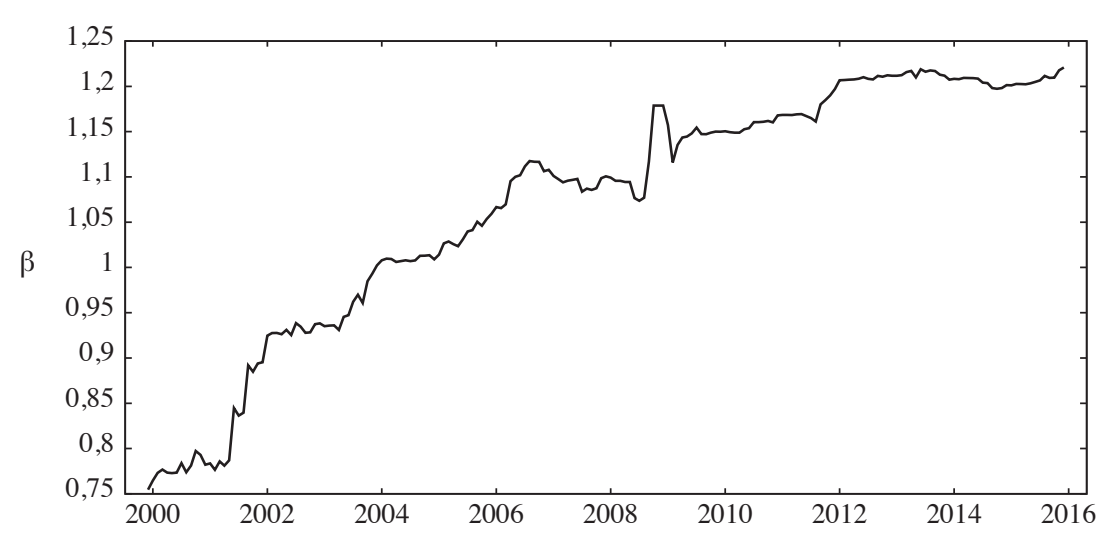

Rys. 3. Wartości $\beta$ (metoda I)

Źródło: opracowanie własne.

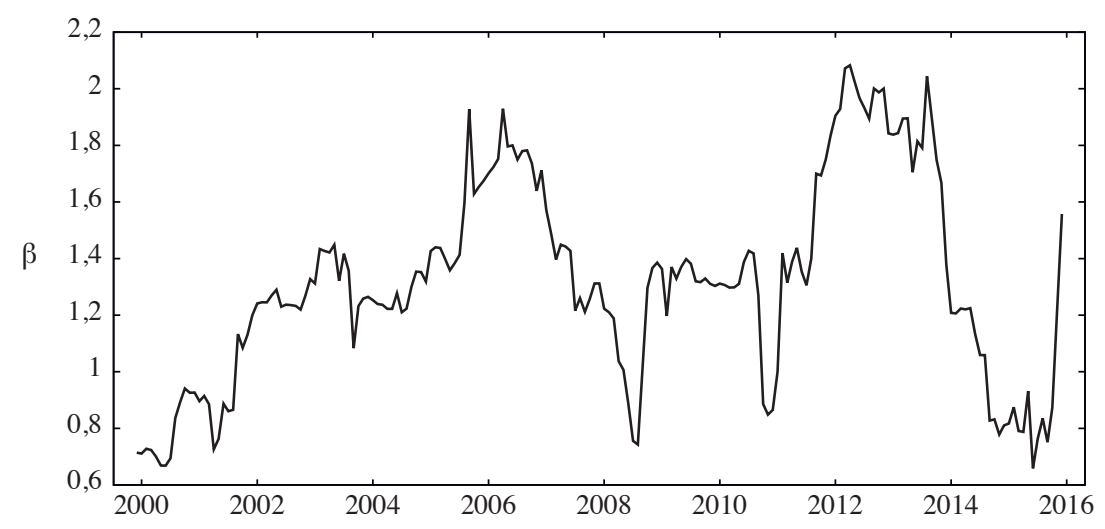

Rys. 4. Wartości $\beta$ (metoda II)

Źródło: opracowanie własne.

Badanie stabilności relacji pomiędzy ryzykiem a zyskiem opiera się na sprawdzeniu stacjonarności szeregu $\beta$. Rys. 3 przedstawia, jak kształtowała się wartość współczynnika $\beta$ wyliczanego za pomocą metody I, natomiast rys. 4 - za pomocą metody II.

W celu zbadania stacjonarności współczynnika $\beta$ wykonano rozszerzony test Dickeya-Fullera dla obu sposobów liczenia $\beta$ (przyjęto poziom istotności równy 
0,05). Obliczenia przeprowadzono za pomocą programu GRETL. Wyniki zostały przedstawione w tabeli 2 .

Tabela 2. Rozszerzony test Dickeya-Fullera dla procesu $\beta$

\begin{tabular}{|l|l|c|}
\hline \multicolumn{1}{|c|}{$\begin{array}{c}\text { Metoda wyliczania } \\
\text { współczynnika } \beta\end{array}$} & \multicolumn{1}{|c|}{ Rodzaj testu } & $p$-value \\
\hline \multirow{2}{*}{ Metoda I } & Test z wyrazem wolnym & 0,09964 \\
\cline { 2 - 4 } & $\begin{array}{l}\text { Test z wyrazem wolnym } \\
\text { i trendem liniowym }\end{array}$ & 0,6457 \\
\hline \multirow{2}{*}{ Metoda I - pierwsze przyrosty } & Test z wyrazem wolnym & 0,0000 \\
\cline { 2 - 4 } & $\begin{array}{l}\text { Test z wyrazem wolnym } \\
\text { i trendem liniowym }\end{array}$ & 0,0000 \\
\hline \multirow{2}{*}{ Metoda II } & Test z wyrazem wolnym & 0,6267 \\
\cline { 2 - 4 } & $\begin{array}{l}\text { Test z wyrazem wolnym } \\
\text { i trendem liniowym }\end{array}$ & 0,0000 \\
\hline \multirow{2}{*}{ Metoda II - pierwsze przyrosty } & Test z wyrazem wolnym & $\begin{array}{l}\text { Test z wyrazem wolnym } \\
\text { i trendem liniowym }\end{array}$ \\
\hline
\end{tabular}

Źródło: opracowanie własne.

Rezultaty wykazały, że proces wartości współczynników $\beta$ jest zintegrowany w stopniu 1 dla obu metod ich wyliczania. Wyniki $p$-value zbliżone do zera są mniejsze od zakładanego poziomu istotności dla pierwszych przyrostów, co oznacza, że można odrzucić hipotezę zerową o niestacjonarności. Ponieważ proces $\beta$ nie jest stacjonarny, można uznać, że wniosek o braku stabilności wartości premii za ryzyko jest poprawny.

Wniosek o zmiennej skuteczności strategii został przetestowany na transakcjach opartych na tzw. efekcie stycznia. Strategia oparta na efekcie stycznia polega na kupowaniu akcji pod koniec grudnia i sprzedawaniu w ostatnim dniu stycznia kolejnego roku. Efekt stycznia to występowanie wysokich stóp zwrotu (w porównaniu z innymi miesiącami tego roku) z inwestycji w akcje w styczniu [Grotowski 2008]. W pracy przyjęto, że efekt stycznia występuje, gdy w pierwszym miesiącu roku stopa zwrotu jest wyższa od poziomu prostej średniej arytmetycznej dla tego roku. Występowanie tej anomalii tłumaczone jest mechanizmami występującymi w prawie podatkowym. Pod koniec grudnia, w warunkach chwilowej bessy, inwestorzy odsprzedają akcje, aby zrealizować stratę i uzyskać odpis podatkowy. $\mathrm{Z}$ początkiem nowego roku następuje hossa, którą wzmagają też inwestorzy instytucjonalni zarządzający funduszami inwestycyjnymi, by wykazać atrakcyjną strukturę portfeli inwestycyjnych. To zwiększa popyt na dane akcje, a co za tym 
idzie - ich ceny. Przykładowo na Giełdzie Papierów Wartościowych w Warszawie efekt stycznia wystąpił tylko w 13 na 24 lata (tabela 3), tj. w 54\% przypadków.

Tabela 3. Stopy zwrotu uzyskane za pomocą strategii opartej na tzw. efekcie stycznia (indeks WIG)

\begin{tabular}{|c|c|c|c|c|c|}
\hline Lata & Grudzień & Styczeń & $\begin{array}{c}\text { Stopa zwrotu } \\
\text { w styczniu (w \%) }\end{array}$ & $\begin{array}{c}\text { Średnia stopa } \\
\text { zwrotu w danym } \\
\text { roku (w \%) }\end{array}$ & Efekt stycznia \\
\hline $1991 / 1992$ & 919,10 & 937,40 & 1,99 & $-0,36$ & występuje \\
\hline $1992 / 1993$ & 1046,60 & 1050,50 & 0,37 & 1,03 & występuje \\
\hline $1993 / 1994$ & 12439,00 & 16881,00 & 35,71 & 20,68 & występuje \\
\hline $1994 / 1995$ & 7473,10 & 6153,00 & $-17,66$ & $-4,25$ & nie występuje \\
\hline $1995 / 1996$ & 7585,90 & 10413,10 & 37,27 & 0,12 & występuje \\
\hline $1996 / 1997$ & 14342,80 & 16105,50 & 12,29 & 5,31 & występuje \\
\hline $1997 / 1998$ & 14668,00 & 14601,50 & $-0,45$ & 0,19 & nie występuje \\
\hline $1998 / 1999$ & 12795,60 & 14573,50 & 13,89 & $-1,14$ & występuje \\
\hline $1999 / 2000$ & 18083,60 & 19398,00 & 7,27 & 2,88 & występuje \\
\hline $2000 / 2001$ & 17847,60 & 17602,90 & $-1,37$ & $-0,11$ & nie występuje \\
\hline $2001 / 2002$ & 13922,20 & 16062,80 & 15,38 & $-2,07$ & występuje \\
\hline $2002 / 2003$ & 14366,70 & 13844,80 & $-3,63$ & 0,26 & nie występuje \\
\hline $2003 / 2004$ & 20820,10 & 21947,20 & 5,41 & 3,09 & występuje \\
\hline $2004 / 2005$ & 26636,20 & 25993,00 & $-2,41$ & 2,05 & nie występuje \\
\hline $2005 / 2006$ & 35600,80 & 37854,90 & 6,33 & 2,42 & występuje \\
\hline $2006 / 2007$ & 50411,80 & 53717,90 & 6,56 & 2,90 & występuje \\
\hline $2007 / 2008$ & 55648,50 & 47747,80 & $-14,20$ & 0,82 & nie występuje \\
\hline $2008 / 2009$ & 27228,60 & 24685,40 & $-9,34$ & $-5,96$ & nie występuje \\
\hline $2009 / 2010$ & 39986,00 & 40058,30 & 0,18 & 3,20 & nie występuje \\
\hline $2010 / 2011$ & 47489,91 & 47156,76 & $-0,70$ & 1,43 & nie występuje \\
\hline $2011 / 2012$ & 37595,44 & 40927,75 & 8,86 & $-1,95$ & występuje \\
\hline $2012 / 2013$ & 47460,59 & 46840,15 & $-1,31$ & 1,94 & nie występuje \\
\hline $2013 / 2014$ & 51284,25 & 50831,61 & $-0,88$ & 0,02 & nie występuje \\
\hline $2014 / 2015$ & 51416,08 & 52040,24 & 1,21 & $-0,84$ & występuje \\
\hline
\end{tabular}

Źródło: opracowanie własne.

W analogicznym okresie na Deutsche Börse AG efekt ten wystąpił 14 razy (tabela 4). Warto zauważyć, że w przypadku Giełdy Papierów Wartościowych w Warszawie w ostatnich latach efekt stycznia występuje rzadziej. Jest to spowodowane tym, że coraz więcej inwestorów jest świadomych jego występowania. 
Anomalie sezonowe mają to do siebie, że im więcej osób opiera na nich swoje strategie inwestycyjne, tym rzadziej one występują (istnieje zatem proces uczenia się jednostek opisywany w AMH). Jest to przykładowa strategia, która pokazuje, że w zależności od przyjętego okresu wyniki uzyskiwane dzięki niej mogą być różne.

Tabela 4. Stopy zwrotu uzyskane za pomocą strategii opartej na tzw. efekcie stycznia (indeks DAX)

\begin{tabular}{|c|c|c|c|c|c|}
\hline Lata & Grudzień & Styczeń & $\begin{array}{c}\text { Stopa zwrotu } \\
\text { w styczniu (w \%) }\end{array}$ & $\begin{array}{c}\text { Średnia stopa } \\
\text { zwrotu w danym } \\
\text { roku (w \%) }\end{array}$ & Efekt stycznia \\
\hline $1991 / 1992$ & 1578,00 & 1687,50 & 6,94 & $-0,16$ & występuje \\
\hline $1992 / 1993$ & 1545,10 & 1571,90 & 1,73 & 3,19 & nie występuje \\
\hline $1993 / 1994$ & 2266,70 & 2177,50 & $-3,94$ & $-0,61$ & nie występuje \\
\hline $1994 / 1995$ & 2106,60 & 2021,30 & $-4,05$ & 0,56 & nie występuje \\
\hline $1995 / 1996$ & 2253,90 & 2470,10 & 9,59 & 2,07 & występuje \\
\hline $1996 / 1997$ & 2888,70 & 3035,20 & 5,07 & 3,17 & występuje \\
\hline $1997 / 1998$ & 4224,30 & 4442,50 & 5,17 & 1,41 & występuje \\
\hline $1998 / 1999$ & 5002,39 & 5159,96 & 3,15 & 2,75 & występuje \\
\hline $1999 / 2000$ & 6958,14 & 6835,60 & $-1,76$ & $-0,65$ & nie występuje \\
\hline $2000 / 2001$ & 6433,61 & 6795,14 & 5,62 & $-1,84$ & występuje \\
\hline $2001 / 2002$ & 5160,10 & 5107,61 & $-1,02$ & $-4,82$ & występuje \\
\hline $2002 / 2003$ & 2892,63 & 2747,83 & $-5,01$ & 2,63 & nie występuje \\
\hline $2003 / 2004$ & 3965,16 & 4058,60 & 2,36 & 0,59 & występuje \\
\hline $2004 / 2005$ & 4256,08 & 4254,85 & $-0,03$ & 2,00 & nie występuje \\
\hline $2005 / 2006$ & 5408,25 & 5674,14 & 4,92 & 1,66 & występuje \\
\hline $2006 / 2007$ & 6596,91 & 6789,10 & 2,91 & 1,68 & występuje \\
\hline $2007 / 2008$ & 8067,31 & 6851,75 & $-15,07$ & $-4,31$ & nie występuje \\
\hline $2008 / 2009$ & 4810,20 & 4338,35 & $-9,81$ & 1,42 & nie występuje \\
\hline $2009 / 2010$ & 5957,43 & 5608,79 & $-5,85$ & 1,24 & nie występuje \\
\hline $2010 / 2011$ & 6914,19 & 7077,48 & 2,36 & $-1,32$ & występuje \\
\hline $2011 / 2012$ & 5898,35 & 6458,91 & 9,50 & 2,13 & występuje \\
\hline $2012 / 2013$ & 7612,39 & 7776,05 & 2,15 & 1,89 & występuje \\
\hline $2013 / 2014$ & 9552,16 & 9306,48 & $-2,57$ & 0,22 & nie występuje \\
\hline $2014 / 2015$ & 9805,55 & 10694,32 & 9,06 & $-0,73$ & występuje \\
\hline & & & & \\
\hline & & & & & \\
\hline
\end{tabular}

Źródło: opracowanie własne. 


\section{Podsumowanie}

Hipoteza rynku adaptacyjnego stanowi interesującą koncepcję, która zmienia dotychczasowe postrzeganie rynków finansowych. Stanowi ona logiczną i spójną teorię, która pozwala na połączenie hipotezy rynku efektywnego z najnowszymi badaniami nad zachowaniami inwestorów.

Jej główną wadą, podobnie jak w przypadku finansów behawioralnych, jest brak formalnej matematycznej postaci, co utrudnia jej weryfikację. Nie wszystkie wnioski można poddać weryfikacji statystycznej, nie ma również możliwości stworzenia wiarygodnych prognoz opartych na AMH. Jak wykazano w artykule, AMH może jednak stanowić wartościowe rozwinięcie hipotezy rynku efektywnego. AMH potwierdza wniosek o zależności pomiędzy ryzykiem a zyskiem, podając jednocześnie przyczyny niestabilności tej relacji. Wniosek, że strategie inwestycyjne są skuteczne lub nieskuteczne w zależności od sytuacji rynkowej, tłumaczy znane inwestorom tzw. efekty kalendarzowe czy cykliczne anomalie, dzięki którym można uzyskać ponadprzeciętne zyski z inwestycji. Powyższe argumenty sprawiają, że AMH jest teorią, która może mieć istotny wpływ na rozwój nauki o rynkach finansowych.

\section{Literatura}

Akram F., Rime D., Sarno L. [2007], Arbitrage in the Foreign Exchange Market: Turning on the Microscope, CEPR, University of Warwick, London.

Elton E.J., Gruber M.J. [1998], Nowoczesna teoria portfelowa i analiza papierów wartościowych, WIG-Press, Warszawa.

Grossman S., Stiglitz J. [1980], On the Impossibility of Informationally Efficient Markets, „American Economic Review”, vol. 70.

Grotowski M. [2008], Efekty kalendarzowe na Giełdzie Papierów Wartościowych w Warszawie, „Gospodarka Narodowa”, nr 1-2.

Kahneman D., Tversky A. [1979], Prospect Theory: An Analysis of Decision under Risk, „Econometrica”, vol. 47, nr 2, https://doi.org/10.2307/1914185.

Kahneman D., Tversky A. [1982], Belief in the Law of Small Numbers [w:] Judgment under Uncertainty: Heuristics and Biases, eds D. Kahneman, P. Slovic, A. Tversky, Cambridge University Press, Cambridge.

Kian-Ping L. [2007], Ranking Market Efficiency for Stock Markets: A Nonlinear Perspective, „Physica A: Statistical Mechanics and its Applications”, vol. 376, https://doi. org/10.1016/j.physa.2006.10.013.

Kim J.H., Shamsuddin A., Kian-Ping L. [2011], Stock Return Predictability and the Adaptive Markets Hypothesis: Evidence from Century-Long U.S. Data, ,Journal of Empirical Finance", vol. 18, nr 5, https://doi.org/10.1016/j.jempfin.2011.08.002.

Lo A. [1997], Market Efficiency: Stock Market Behavior in Theory and Practice, vols 1, 2, Edward Elgar Publishing, Cheltenham. 
Lo A. [2004], The Adaptive Markets Hypothesis: Market Efficiency from an Evolutionary Perspective, ,Journal of Portfolio Management”, vol. 30, nr 5, https://doi.org/10.3905/ jpm.2004.4426111.

Lo A. [2005], Reconciling Efficient Markets with Behavioral Finance: The Adaptive Markets Hypothesis, ,Journal of Investment Consulting”, vol. 7, nr 2.

Malkiel B.G. [2014], Błądzqc po Wall Street, Wolters Kluwer, Warszawa.

Olbrys. J. [2014], Zastosowanie wybranych miar płynności aktywów kapitałowych na Giełdzie Papierów Wartościowych w Warszawie SA, ,Zarządzanie i Finanse”, nr 12.

Popović S., Mugoša A., Durović A. [2013], Adaptive Markets Hypothesis: Empirical Evidence from Montenegro Equity Market, „Ekonomska Istraživanja - Economic Research", vol. 26, nr 3, https://doi.org/10.1080/1331677x.2013.11517620.

Reilly F.K., Brown K.C. [2001], Analiza inwestycji i zarzqdzanie portfelem, t. 1 i 2, PWE, Warszawa.

Schumpeter J. [1939], Business Cycles: A Theoretical, Historical, and Statistical Analysis of the Capitalist Process, McGraw-Hill, New York.

Shiller R.J. [2003], From Efficient Markets Theory to Behavioral Finance, ,Journal of Economic Perspectives", vol. 17, nr 1, https://doi.org/10.1257/089533003321164967.

Shleifer A., Vishny R. [1997], The Limits of Arbitrage, „Journal of Finance”, vol. 52, nr 1, https://doi.org/10.1111/j.1540-6261.1997.tb03807.x.

Simon H. [1955], A Behavioral Model of Rational Choice, „Quarterly Journal of Economics", vol. 69, https://doi.org/10.2307/1884852.

Todea A., Ulici M., Silaghi S. [2009], Adaptive Markets Hypothesis: Evidence from Asia-Pacific Financial Markets, „Review of Finance and Banking”, vol. 01(1).

Wilson E.O. [1975], Sociobiology: The New Synthesis, Belknap Press of Harvard University Press, Cambridge.

\section{Verification of Selected Applications of the Adaptive Market Hypothesis on the Financial Markets}

(Abstract)

The article presents a model describing the operation of financial markets - the adaptive market hypothesis (AMH), created by Andrew Lo. AMH builds on the theory of efficient market hypothesis (EMH), which allows one to connect EMH with conclusions from behavioral finance. The study examines the conclusions of $\mathrm{AMH}$ about the existence of the unstable relationship between return and risk, and the time-dependent efficiency of investment strategies. The conclusions' verification is based on the example of KGHM Polska Miedź SA, the WIG index and the DAX index. The first conclusion was tested by using the capital asset pricing model, while the second conclusion was verified using an investment strategy based on the "January effect". As the results show, both applications proved correct.

Keywords: adaptive market hypothesis, CAPM, behavioral finance, efficient market hypothesis. 